\section{Fresh Market Tomato Yield and Soil Nitrogen as Affected by Tillage, Cover Cropping, and Nitrogen Fertilization}

\author{
Sidat Yaffa, Upendra M. Sainju ${ }^{1}$, and Bharat P. Singh \\ Agricultural Research Station, Fort Valley State University, Fort Valley, \\ GA 31030-3298
}

K.C. Reddy

Plant and Soil Science Department, Alabama A\&M University, Normal, AL 35762

Additional index words. Lycopersicon esculentum, nitrogen uptake, hairy vetch, Vicia villosa, mulch, soil nitrogen, leaching, sustainable agriculture

\begin{abstract}
Sustainable practices are needed in vegetable production to maintain yield and to reduce the potential for soil erosion and $\mathrm{N}$ leaching. We examined the effects of tillage [no-till (NT), chisel plowing (CP), and moldboard plowing (MP)], cover cropping [hairy vetch (Vicia villosa Roth) vs. winter weeds], $N$ fertilization $\left(0,90\right.$, and $\left.180 \mathrm{~kg} \cdot \mathrm{ha}^{-1} \mathrm{~N}\right)$, and date of sampling on tomato (Lycopersicon esculentum Mill.) yield, $\mathbf{N}$ uptake, and soil inorganic $\mathrm{N}$ in a Norfolk sandy loam in Fort Valley, Ga. for 2 years. Yield was greater with CP and MP than with NT in 1996 and was greater with 90 and 180 than with $0 \mathrm{~kg} \cdot \mathrm{ha}^{-1} \mathrm{~N}$ in 1996 and 1997 . Similarly, aboveground tomato biomass (dry weight of stems + leaves + fruits) and N uptake were greater with CP and MP than with NT from 40 to 118 days after transplanting (DAT) in 1996; greater with hairy vetch than with winter weeds at $82 \mathrm{DAT}$ in 1997; and greater with 90 or 180 than with $0 \mathrm{~kg} \cdot \mathrm{ha}^{-1} \mathrm{~N}$ at 97 DAT in 1996 and at 82 DAT in 1997. Soil inorganic N was greater with NT or CP than with MP at 0 - to 10-cm depth at 0 and 30 DAT in 1996; greater with hairy vetch than with winter weeds at $0-$ to $10-\mathrm{cm}$ and at $10-$ to $30-\mathrm{cm}$ at 0 DAT in 1996 and 1997, respectively; and greater with 90 or 180 than with $0 \mathrm{~kg}^{\circ} \mathrm{ha}^{-1} \mathrm{~N}$ from 30 to $116 \mathrm{DAT}$ in 1996 and 1997. Levels of soil inorganic $N$ and tomato $N$ uptake indicated that $N$ release from cover crop residues was synchronized with $\mathrm{N}$ need by tomato, and that $\mathrm{N}$ fertilization should be done within 8 weeks of transplanting. Similar tomato yield, biomass, and $N$ uptake with $C P$ vs. MP and with 90 vs. $180 \mathrm{~kg} \cdot \mathrm{ha}^{-1} \mathrm{~N}$ suggests that minimum tillage, such as CP, and 90 $\mathbf{k g} \cdot \mathrm{ha}^{-1} \mathrm{~N}$ can better sustain tomato yield and reduce potentials for soil erosion and $\mathrm{N}$ leaching than can conventional tillage, such as MP, and $180 \mathrm{~kg} \cdot \mathrm{ha}^{-1} \mathrm{~N}$, respectively. Because of increased vegetative cover in the winter, followed by increased mulch and soil $\mathrm{N}$ in the summer, hairy vetch can reduce the potential for soil erosion and the amount of $\mathrm{N}$ fertilization required for tomato better than can winter weeds.
\end{abstract}

Optimum production of tomatoes requires intensive management and high input of $\mathrm{N}$ (Univ. of Georgia, 1995). As a result, deterioration of soil and water quality may occur from soil erosion and $\mathrm{NO}_{3}$ leaching to the groundwater. Excessive $\mathrm{N}$ fertilization accompanied by poor soil and crop management practices have increased $\mathrm{NO}_{3}$ pollution in groundwater (Hallberg, 1989). Although $\mathrm{NO}_{3}$ pollution results from several sources, such as industrial wastes, municipal landfills, mining, and septic systems, agricultural practices remain a major source (Hallberg et al., 1985; United States Environmental Protection Agency, 1992). Therefore, practices that conserve and manage soil and nutrients are needed for maintain-

Received for publication 10 Dec. 1999. Accepted for publication 13 Apr. 2000. The cost of publishing this paper was defrayed in part by the payment of page charges. Under postal regulations, this paper therefore must be hereby marked advertisement solely to indicate this fact.

${ }^{1}$ To whom requests for reprints should be addressed. E-mail address: sainjuu@mail.fvsu.edu ing soil and water quality and for sustaining tomato productivity.

Tillage oxidizes soil organic matter, disrupts aggregates, and increases aeration (Balesdent et al., 1990; Cambardella and Elliott, 1993). Therefore, amendments or plant residues need to be added to the soil to replace organic matter lost by tillage (Cambardella and Elliott, 1993; Collins et al., 1992). Practices that reduce residue incorporation and aggregate degradation, such as no-till or minimum till, can conserve soil organic matter (Franzluebbers et al., 1995; Havlin et al., 1990).

Cover crops such as hairy vetch, planted in the fall after summer crops, utilize residual $\mathrm{NO}_{3}$ in the soil and reduce its loss by leaching (Sainju and Singh, 1997, Sainju et al., 1998). Cover crops provide vegetative cover on erosion-prone soils in the winter (Frankenberger and Abdelmagid, 1985; Smith et al., 1987) and improve physical, chemical, and biological properties of the soil (Power and Doran, 1988; Vigil and Kissel, 1991). Because legume cover crops fix $\mathrm{N}$ from the atmosphere, they can provide substantial amounts of $\mathrm{N}$ for the suc- ceeding crops (Frye et al., 1988; Hargrove, 1986; Vigil and Kissel, 1991). This can reduce the amount of $\mathrm{N}$ fertilizer applied. Legume cover crops increase the yield of summer crops more than do nonlegumes or no cover crop, with yield increases equivalent to that produced by $\mathrm{N}$ fertilization at 15 to $200 \mathrm{~kg} \cdot \mathrm{ha}^{-1} \mathrm{~N}$ (Sainju and Singh, 1997).

Tomato is one of the important vegetable crops in Georgia (Univ. of Georgia, 1995). Because it requires a relatively higher management intensity and larger input of $\mathrm{N}$, a greater potential for leaching of $\mathrm{N}$ exists under tomato than under cereal crops (Power and Schepers, 1989). Lower recovery of $\mathrm{N}$ by tomato than by cereal crops (Creamer et al., 1996; Lowrance and Smittle, 1988; Sweeney et al., 1987) also results in increased potential for $\mathrm{N}$ leaching. Therefore, research is required to develop a production system that protects groundwater quality without reducing yield. One approach is to use conservation tillage combined with cover cropping and reduced $\mathrm{N}$ fertilization. Little is known about the combined effects of tillage, cover cropping, and $\mathrm{N}$ fertilization on tomato yield and soil mineral N. Our objectives were to: 1) determine the effects of tillage, hairy vetch cover cropping, $\mathrm{N}$ fertilization, and date of sampling on yield and $\mathrm{N}$ uptake by transplanted tomato and soil inorganic $\mathrm{N}$; 2) examine whether $\mathrm{N}$ release by cover crop residues and time of $\mathrm{N}$ fertilization are synchronized with $\mathrm{N}$ need by tomato; and 3) relate soil inorganic $\mathrm{N}$ to tomato yield and $\mathrm{N}$ uptake.

\section{Materials and Methods}

Field experiment. The experiment was initiated in Sept. 1994 at the Agricultural Research Station farm, Fort Valley State Univ., Fort Valley, Ga. on a Norfolk sandy loam (fine loamy, siliceous, thermic, Typic Kandiudults). The soil had $650 \mathrm{~g} \cdot \mathrm{kg}^{-1}$ sand, $250 \mathrm{~g} \cdot \mathrm{kg}^{-1}$ silt, $100 \mathrm{~g} \cdot \mathrm{kg}^{-1}$ clay, a $\mathrm{pH}$ of $6.5,8.7 \mathrm{~g} \cdot \mathrm{kg}^{-1}$ organic $\mathrm{C}$, and $635 \mathrm{mg} \cdot \mathrm{kg}^{-1}$ organic $\mathrm{N}$ at $0-$ to $30-\mathrm{cm}$ depth. Previous cropping history was double cropping of wheat (Triticum sp.) and soybean [Glycine $\max$ L. (Merr.)] for 2 years followed by corn (Zea mays L.) for 3 years. Temperature and rainfall data were collected from a weather station $20 \mathrm{~m}$ from the site.

The treatments consisted of three levels of tillage [no-till (NT), chisel plowing (CP), and moldboard plowing (MP)], two levels of cover crop (hairy vetch vs. winter weeds), and three levels of $\mathrm{N}$ fertilization $(0,90$, and 180 $\left.\mathrm{kg} \cdot \mathrm{ha}^{-1} \mathrm{~N}\right)$. The CP was considered as minimum tillage and consisted of harrowing (10 $15 \mathrm{~cm}$ depth), followed by chiseling (20-25 $\mathrm{cm}$ depth) and leveling with a S-tine harrow. Similarly, conventional tillage, such as MP, consisted of harrowing, followed by moldboard plowing (20-25 cm depth) and leveling. The recommended dose of $\mathrm{N}$ fertilizer for tomato is $180 \mathrm{~kg} \cdot \mathrm{ha}^{-1} \mathrm{~N}$ in central Georgia (Univ. of Georgia, 1995). The treatments were arranged in a split-split-plot design where tillage was used as the main treatment, cover crop as the split-plot treatment, and $\mathrm{N}$ fertilization as the split-split-plot treatment. Each treat- 
ment was replicated three times. The experimental unit was $7.2 \times 7.2 \mathrm{~m}$.

The CP and MP plots were tilled two times a year: in September or October for cover crop planting and in April for tomato transplanting. Plots were harrowed two to three times until plant residues were broken into small pieces and soil particles were loosened before plowing. The NT plots were left undisturbed except for drilling cover crop seed, transplanting tomato seedlings, and hand weeding at the soil surface. Although the experiment was started in 1994, observations were taken only from 1995 to 1997.

On 13 Sept. 1995 and 11 Oct. 1996, CP and MP plots in the same area were harrowed, plowed, and leveled. Hairy vetch seed was inoculated with Rhizobium leguminosarum (bv. viceae) and drilled at $28 \mathrm{~kg} \cdot \mathrm{ha} \mathrm{a}^{-1}$, with a row spacing of $15 \mathrm{~cm}$. No fertilizer, herbicide, or insecticide was applied. On 11 Apr. 1996 and 31 Mar. 1997, hairy vetch was harvested at flowering stage from two $30 \times 30 \mathrm{~cm}^{2}$ areas from central rows within the plot for biomass and $\mathrm{N}$ concentration determinations. In the weed plots, winter weeds [dominated by henbit (Lamium amplexicaule L.) and cut-leaf evening primrose (Oenothera laciniata L.)] were collected as above. Plant residues were ovendried at $60^{\circ} \mathrm{C}$, weighed, and ground to pass a 1-mm screen for $\mathrm{N}$ analysis. After sampling, cover crop and winter weeds were mowed with a tractor-drawn rotary mower. Plant residues in NT plots were killed by spraying with $3.36 \mathrm{~kg} \cdot \mathrm{ha}^{-1}$ of glyphosate [N-(phosphonomethyl) glycine] and served as mulch on the soil surface. In CP and MP plots, residues were incorporated into the soil by harrowing two to three times, followed by plowing. Residues were allowed to decompose in the soil for 2 weeks before transplanting tomatoes.

On 24 Apr. 1996 and 18 Apr. 1997, P (from triple superphosphate) and $\mathrm{K}$ (from muriate of potash) were broadcast at $56 \mathrm{~kg} \cdot \mathrm{ha}^{-1}$ each in all plots based on the soil test, along with diazinon [diethyl 0-(2-isopropyl-6 methyl-4 pyrimidinyl) phosphorothioate] (3.35 kg $\cdot \mathrm{ha}^{-1}$, a.i.) to control cutworms. To control weeds, $0.57 \mathrm{~kg} \cdot \mathrm{ha}^{-1}$ of trifluralin [2, 6-dinitro-Ndipropyl-4-(trifluoromethyl) benzenamine] was broadcast in CP and MP plots and the herbicide was incorporated to a depth of $8 \mathrm{~cm}$ by light harrowing and leveling. In NT plots, weeds were controlled by weeding at the soil surface with a hand hoe every week throughout tomato growth.

On 25 Apr. 1996 and 19 Apr. 1997, 5week-old tomato (cv. Sunbeam) seedlings grown on $2.5 \times 2.5 \times 5 \mathrm{~cm}$ cells were handtransplanted at a spacing of $0.9 \times 0.9 \mathrm{~m}$. Each experimental unit contained eight rows of tomatoes $7.2 \mathrm{~m}$ long, each row spaced $0.9 \mathrm{~m}$ apart. This spacing was used to produce large fruits (Univ. of Georgia, 1995). Starter solution containing $3 \mathrm{~g} \cdot \mathrm{L}^{-1}$ each of $\mathrm{N}, \mathrm{P}$, and $\mathrm{K}(0.4$ $\left.\mathrm{kg} \cdot \mathrm{ha}^{-1}\right)$ was applied to each tomato plant after 1 week to encourage early establishment. Nitrogen fertilizer (nitrate of soda, 16\% N) was split into three doses. Each dose was sidedressed by hand broadcasting at 3-week inter- vals [i.e., 21, 42, and $63 \mathrm{~d}$ after transplanting (DAT)]. Overhead irrigation (reel rain gun, 25 mm per application) was applied immediately after fertilization and during tomato growth as needed to prevent moisture stress. Irrigation was applied at 2, 12, 22, 32, 42, and 64 DAT in 1996 and at 2, 11, 22, and 44 DAT in 1997.

From 3 June to 20 Aug. 1996 and 14 May to 31 July 1997 , two tomato plants $\left(1.62 \mathrm{~m}^{2}\right.$ area) were harvested from two middle rows every 20 to $29 \mathrm{~d}$. These were separated into fruits, leaves, and stems, and oven-dried, weighed, and ground to pass a 1-mm screen for $\mathrm{N}$ analysis. In addition, in July and Aug. 1996 and 1997, fruits were harvested from five plants $\left(4.05 \mathrm{~m}^{2}\right.$ area $)$ from two middle rows for the measurement of fresh yield. Fruits were harvested and weighed twice a week as the color turned from green to pink. Total fresh market tomato yield was determined by adding individual weight obtained at one picking after removing culls. Soil samples were collected at 0 - to 10- and 10- to 30-cm depths from Apr. to Aug. 1996 and 1997 immediately after transplanting and every month thereafter. These were collected from five places within middle rows with a push tube ( $5 \mathrm{~cm}$ diam.), composited within a depth, air-dried, and sieved to $2 \mathrm{~mm}$.

Laboratory analysis. Nitrogen concentration in the cover crop and tomato samples was determined by the method described by Kuo et al. (1997). Carbon concentration in the cover crop sample was determined by the WalkeyBlack method (Nelson and Sommers, 1996), assuming all $\mathrm{C}$ was digested. Nitrogen accumulated in the cover crop and taken up by aboveground tomato biomass (leaves + stems + fruits) was determined by multiplying dry matter yield by $\mathrm{N}$ concentration.

Nitrate and $\mathrm{NH}_{4}^{+}$concentrations in the soil were determined by steam distillation after extracting with $2 \mathrm{M} \mathrm{KCl}$ (Mulvaney, 1996). Inorganic $\mathrm{N}$ was determined as the sum of $\mathrm{NH}_{4}{ }^{+}$and $\mathrm{NO}_{3}{ }^{-}$concentrations.

Data analysis. Data for soil and plant parameters were analyzed using the MIXED procedure of SAS after testing for homogeneity of variance (Littell et al., 1996). Sources of variation included tillage, cover crop, $\mathrm{N}$ fertilization, date of sampling, and their interac- tions. The least square means test was used to determine significant differences between means when treatment interactions were significant. Correlation analysis was used to determine the relationship between cover crop characteristics, soil inorganic $\mathrm{N}$, and tomato aboveground biomass and $\mathrm{N}$ uptake on mean values of three replications. Statistical significance was evaluated at $P \leq 0.05$.

\section{Results}

Cover crop characteristics. Cover crop significantly influenced biomass yield, $\mathrm{N}$ concentration, $\mathrm{N}$ accumulation, and $\mathrm{C}: \mathrm{N}$ ratio of cover crops, but effects of tillage and tillage $\times$ cover crop interaction were nonsignificant (Table 1). Averaged across tillage methods, biomass was two- to three-fold as great, $\mathrm{N}$ concentration was one and half- to two-fold as great, and $\mathrm{N}$ accumulation was two- to six-fold as great for hairy vetch as for winter weeds. The $\mathrm{C}: \mathrm{N}$ ratio was lower in hairy vetch than in winter weeds. Nitrogen concentration and $\mathrm{N}$ accumulation in hairy vetch and winter weeds were lower in 1997 than in 1996 (Table 1). The lower $N$ concentration or higher $C: N$ ratio of hairy vetch in 1997 probably resulted from a greater proportion of winter weeds that were not controlled by the cover crop.

Fresh market tomato yield. Fresh market tomato yield was significantly influenced by tillage in 1996 and by $\mathrm{N}$ fertilization in 1996 and 1997, but cover crop did not affect yield (Table 2). No interactions were significant. Tomato yield was greater with $\mathrm{CP}$ and MP than with NT in 1996 and was greater with 90 and 180 than with $0 \mathrm{~kg} \cdot \mathrm{ha}^{-1} \mathrm{~N}$ in 1996 and 1997. Averaged over treatments, yield was 41\% greater in 1996 than in 1997.

Tomato aboveground biomass and $N$ uptake. Dry biomass of stems + leaves + fruits and $\mathrm{N}$ uptake as influenced by tillage, cover cropping, and $\mathrm{N}$ fertilization differed with date of sampling. Both biomass and $\mathrm{N}$ uptake increased from 40 to 97 DAT in 1996 and from 26 to 82 DAT in 1997, then declined (data not shown). During maximum growth at 97 DAT in 1996, biomass and $\mathrm{N}$ uptake were greater with $\mathrm{CP}$ and MP than with NT, and N uptake

Table 1. Effects of tillage and cover crop on cover crop biomass, $\mathrm{N}$ concentration, $\mathrm{N}$ accumulation, and $\mathrm{C}: \mathrm{N}$ ratio in 1996 and 1997.

\begin{tabular}{|c|c|c|c|c|c|c|c|c|}
\hline \multirow[b]{2}{*}{ Treatment } & \multicolumn{2}{|c|}{$\begin{array}{l}\text { Biomass } \\
\left({\left.\mathrm{Mg} \cdot h a^{-1}\right)}\right.\end{array}$} & \multicolumn{2}{|c|}{$\begin{array}{c}\text { N concentration } \\
\left(\mathrm{g} \cdot \mathrm{kg}^{-1}\right)\end{array}$} & \multicolumn{2}{|c|}{$\begin{array}{c}\mathrm{N} \text { accumulation } \\
\left(\mathrm{kg} \cdot \mathrm{ha}^{-1}\right)\end{array}$} & \multicolumn{2}{|c|}{$\mathrm{C}: \mathrm{N}$ ratio } \\
\hline & 1996 & 1997 & 1996 & 1997 & 1996 & 1997 & 1996 & 1997 \\
\hline \multicolumn{9}{|c|}{ Tillage $e^{\mathrm{z}}$} \\
\hline NT & $3.77 \mathrm{a}^{\mathrm{y}}$ & $3.18 \mathrm{a}$ & $27.7 \mathrm{a}$ & $17.0 \mathrm{a}$ & $120 \mathrm{a}$ & $56 a$ & $15.0 \mathrm{a}$ & $26.4 \mathrm{a}$ \\
\hline $\mathrm{CP}$ & $3.84 \mathrm{a}$ & $2.87 \mathrm{a}$ & $27.8 \mathrm{a}$ & $16.0 \mathrm{a}$ & $124 \mathrm{a}$ & $49 \mathrm{a}$ & $15.9 \mathrm{a}$ & $28.2 \mathrm{a}$ \\
\hline MP & $3.50 \mathrm{a}$ & $3.02 \mathrm{a}$ & $28.9 \mathrm{a}$ & $15.9 \mathrm{a}$ & $119 \mathrm{a}$ & $51 \mathrm{a}$ & $13.7 \mathrm{a}$ & $29.2 \mathrm{a}$ \\
\hline \multicolumn{9}{|c|}{ Cover crop $^{\mathrm{x}}$} \\
\hline $\mathrm{HV}$ & $5.47 \mathrm{a}$ & $4.16 \mathrm{a}$ & $37.5 \mathrm{a}$ & $18.5 \mathrm{a}$ & $206 \mathrm{a}$ & $77 \mathrm{a}$ & $11.7 \mathrm{a}$ & $23.6 \mathrm{a}$ \\
\hline WW & $1.94 \mathrm{~b}$ & $1.90 \mathrm{~b}$ & $18.7 \mathrm{~b}$ & $14.1 \mathrm{~b}$ & $37 \mathrm{~b}$ & $27 \mathrm{~b}$ & $18.0 \mathrm{~b}$ & $32.3 \mathrm{~b}$ \\
\hline \multicolumn{9}{|c|}{ Interaction } \\
\hline Tillage $\times$ Cover crop & NS & NS & NS & NS & NS & NS & NS & NS \\
\hline
\end{tabular}

zTillage treatments are NT, no-till; CP, chisel plowing; and MP, moldboard plowing.

${ }^{y}$ Mean separation within columns and main effects by the least square means test, $P \leq 0.05$.

${ }^{\mathrm{x}}$ Cover crops are HV, hairy vetch; and WW, winter weeds [dominated by henbit (Lamium amplexicaule L.) and cut-leaf evening primrose (Oenothera laciniata L.)].

${ }^{\mathrm{N}}$ Nonsignificant. 
was greater with 180 than with $0 \mathrm{~kg} \cdot \mathrm{ha}^{-1} \mathrm{~N}$ (Table 3). Similarly, during maximum growth at 82 DAT in 1997, biomass and $\mathrm{N}$ uptake were greater with hairy vetch than with winter weeds, biomass was greater with 180 and 90 than with $0 \mathrm{~kg} \cdot \mathrm{ha}^{-1} \mathrm{~N}$, and $\mathrm{N}$ uptake was greater with 180 than with $0 \mathrm{~kg} \cdot \mathrm{ha}^{-1} \mathrm{~N}$.

Soil inorganic $N$. Soil inorganic $\mathrm{N}$ at the 10 - to $30-\mathrm{cm}$ depth was significantly influenced by cover crop in 1997 and by $\mathrm{N}$ fertilization and date of sampling in both years at both soil depths (data not shown). Inorganic $\mathrm{N}$ as influenced by tillage, cover cropping, and $\mathrm{N}$ fertilization differed with date of sampling, so results are presented as time-series data.

Inorganic $\mathrm{N}$ increased from 0 to $30 \mathrm{DAT}$ in 1996 and from 28 to 56 DAT in 1997 ,

Table 2. Effects of tillage, cover crop, and $\mathrm{N}$ fertilization on yield of fresh market tomato (cv. Sunbeam) in 1996 and 1997.

\begin{tabular}{|c|c|c|}
\hline \multirow[b]{2}{*}{ Treatment } & 1996 & 1997 \\
\hline & --( & 1) $)-$ \\
\hline \multicolumn{3}{|c|}{ Tillage } \\
\hline No-till & $35.0 \mathrm{a}^{\mathrm{z}}$ & 32.1 \\
\hline Chisel plowing & $66.4 \mathrm{~b}$ & 33.5 \\
\hline Moldboard plowing & $62.9 \mathrm{~b}$ & 30.5 \\
\hline \multicolumn{3}{|c|}{ Cover crop } \\
\hline Hairy vetch & $56.7 \mathrm{a}$ & 34.0 \\
\hline Winter weeds & $53.9 \mathrm{a}$ & 33.4 \\
\hline \multicolumn{3}{|c|}{$N$ fertilization $\left(\mathrm{kg} \cdot \mathrm{ha}^{-l}\right)$} \\
\hline 0 & $49.5 \mathrm{a}$ & 26.6 \\
\hline 90 & $58.1 \mathrm{~b}$ & 36.0 \\
\hline 180 & $56.6 \mathrm{~b}$ & 33.6 \\
\hline \multicolumn{3}{|c|}{ Significance $^{\mathrm{y}}$} \\
\hline Tillage (Till) & ** & NS \\
\hline Cover crop (Ccrop) & NS & NS \\
\hline $\mathrm{N}$ fertilization (Fert) & $*$ & $* *$ \\
\hline
\end{tabular}

$\overline{{ }^{2} \text { Mean separation within columns and main treat- }}$ ments by the least square means test, $P \leq 0.05$.

${ }^{y}$ No interactions were significant at $P \leq 0.05$.

${ }_{\text {ns, }, * * *}$ Nonsignificant or significant at $P \leq 0.05$, or 0.01 , respectively.

Table 3. Effects of tillage, cover crop, and $\mathrm{N}$ fertilization on tomato aboveground biomass (dry weights of stems + leaves + fruits) and $\mathrm{N}$ uptake during maximum growth at $97 \mathrm{~d}$ after transplanting (DAT) in 1996 and at 82 DAT in 1997.

\begin{tabular}{|c|c|c|c|c|}
\hline \multirow[b]{3}{*}{ Treatment } & \multicolumn{2}{|c|}{ Biomass } & \multicolumn{2}{|c|}{$\mathrm{N}$ uptake } \\
\hline & \multirow{2}{*}{97 DAT 1996} & \multirow{2}{*}{$\begin{array}{r}82 \text { DAT } 1997 \\
-1) \cdot-----\end{array}$} & \multirow{2}{*}{$\begin{array}{l}97 \text { DAT } 1996 \\
-----\end{array}$} & \multirow{2}{*}{$\begin{array}{l}82 \text { DAT } 1997 \\
-1)-----\end{array}$} \\
\hline & & & & \\
\hline \multicolumn{5}{|c|}{ Tillage } \\
\hline No-till & $2.73 b^{z}$ & $3.65 \mathrm{a}$ & $70 \mathrm{~b}$ & $118 \mathrm{a}$ \\
\hline Chisel plowing & $3.72 \mathrm{a}$ & $3.22 \mathrm{a}$ & $108 \mathrm{a}$ & $105 \mathrm{a}$ \\
\hline Moldboard plowing & $3.55 \mathrm{a}$ & $3.76 \mathrm{a}$ & $102 \mathrm{a}$ & $116 \mathrm{a}$ \\
\hline \multicolumn{5}{|c|}{ Cover crop } \\
\hline Hairy vetch & $3.36 \mathrm{a}$ & $3.90 \mathrm{a}$ & $93 \mathrm{a}$ & $126 \mathrm{a}$ \\
\hline Winter weeds & $3.30 \mathrm{a}$ & $3.18 \mathrm{~b}$ & $93 \mathrm{a}$ & $100 \mathrm{~b}$ \\
\hline \multicolumn{5}{|c|}{$N$ fertilization $\left(\mathrm{kg} \cdot \mathrm{ha}^{-1}\right)$} \\
\hline 0 & $3.24 \mathrm{a}$ & $3.25 \mathrm{~b}$ & $86 b$ & $105 \mathrm{~b}$ \\
\hline 90 & $3.38 \mathrm{a}$ & $3.65 \mathrm{a}$ & $94 \mathrm{ab}$ & $114 \mathrm{ab}$ \\
\hline 180 & $3.37 \mathrm{a}$ & $3.73 \mathrm{a}$ & $99 \mathrm{a}$ & $120 \mathrm{a}$ \\
\hline \multicolumn{5}{|c|}{ Significance } \\
\hline Tillage (Till) & $* *$ & NS & $* *$ & NS \\
\hline Cover crop (Ccrop) & NS & $*$ & NS & $* *$ \\
\hline Till $\times$ Ccrop & NS & NS & NS & NS \\
\hline $\mathrm{N}$ fertlilization (Fert) & NS & $* *$ & $*$ & $*$ \\
\hline Till $\times$ Fert & NS & NS & NS & NS \\
\hline Ccrop $\times$ Fert & NS & NS & NS & NS \\
\hline Till $\times$ Ccrop $\times$ Fert & NS & NS & NS & NS \\
\hline
\end{tabular}

${ }^{2}$ Mean separation within columns and main treatments by the least square means test, $P \leq 0.05$.

Ns.,**** Nonsignificant or significant at $P \leq 0.05$, or 0.01 , respectively. reduce the potential for soil erosion compared with conventional tillage, such as MP. Similarly, nonsignificant differences in tomato yield, biomass, and $\mathrm{N}$ uptake between 90 and $180 \mathrm{~kg} \cdot \mathrm{ha}^{-1} \mathrm{~N}$ (Tables 2 and 3) indicate that 90 $\mathrm{kg} \cdot \mathrm{ha}^{-1} \mathrm{~N}$ can sustain tomato yield and reduce the cost of $\mathrm{N}$ fertilization and the potential for $\mathrm{N}$ leaching compared with $180 \mathrm{~kg} \cdot \mathrm{ha}^{-1} \mathrm{~N}$.

Hairy vetch did not increase tomato yield over that obtained with winter weeds, although it increased aboveground biomass and $\mathrm{N}$ uptake in 1997 (Table 3). In a related study, Creamer et al. (1996) found that tomato yield was lower with a cover crop mixture containing hairy vetch as the dominant component than without a cover crop. Although hairy vetch increased soil inorganic N (Fig. 1), it did not increase tomato yield, probably because $\mathrm{N}$ status of the soil was not a limiting factor in our study. Without hairy vetch, inorganic $\mathrm{N}$ at both soil depths was $>25 \mathrm{mg} \cdot \mathrm{kg}^{-1}$ at 30 DAT in both years; at this level $\mathrm{N}$ addition is not recommended (Magdoff, 1991). Further studies are needed to evaluate the effect of a hairy vetch cover crop on fresh market tomato, because hairy vetch has been known to substantially increase tomato yield (Abdul-Baki and Teasdale, 1993; Abdul-Baki et al., 1996). Compared with winter weeds, hairy vetch, however, can increase vegetative cover in the winter and soil $\mathrm{N}$ and tomato biomass in the summer, thereby reducing both the potential for soil erosion and the amount of $\mathrm{N}$ fertilization needed.

Increased soil inorganic $\mathrm{N}$ at 0 and $30 \mathrm{DAT}$ in 1996 and at 56 and 89 DAT in 1997, regardless of treatment (Figs. 1 and 2), may have resulted from increased $\mathrm{N}$ mineralization from hairy vetch, weeds, and soil organic matter or greater $\mathrm{N}$ availability from $\mathrm{N}$ fertilization. When ground to $1 \mathrm{~mm}$ and incorporated into the soil, hairy vetch residue released half of its $\mathrm{N}$ within 4 to 8 weeks (Kuo et al., 1997; Stute and Posner, 1995). Increased temperature from April to June also may have increased $\mathrm{N}$ mineralization from plant residue and soil organic matter because $\mathrm{N}$ mineralization is temperature-dependent (Stanford et al., 1975). Average monthly temperature for April and June were 16.1 and $24.6^{\circ} \mathrm{C}$ in 1996 and 15.7 and $22.2{ }^{\circ} \mathrm{C}$ in 1997 , respectively. Although early $\mathrm{N}$ release may favor weed over tomato growth, we controlled weeds with herbicides and hand weeding, which may have recycled $\mathrm{N}$ back to the soil, and therefore may not have significantly altered $\mathrm{N}$ uptake by tomato. The decreased inorganic $\mathrm{N}$ after 56 DAT, however, may have resulted from $\mathrm{N}$ uptake by tomato or losses due to leaching, denitrification, or volatilization.

The increased soil inorganic $\mathrm{N}$ from 0 to 56 DAT and tomato N uptake from 40 to $97 \mathrm{DAT}$, followed by a decline (Figs. 1 and 2, Table 3) suggests that $\mathrm{N}$ release from cover crop residues was synchronized with the $\mathrm{N}$ need of tomato during its early growth, regardless of tillage. Kuo et al. (1997) and Stute and Posner (1995) also observed that $\mathrm{N}$ release from cover crop residues in the soil was synchronized with the $\mathrm{N}$ need of corn during its early growth. Lack of synchronization results in the 


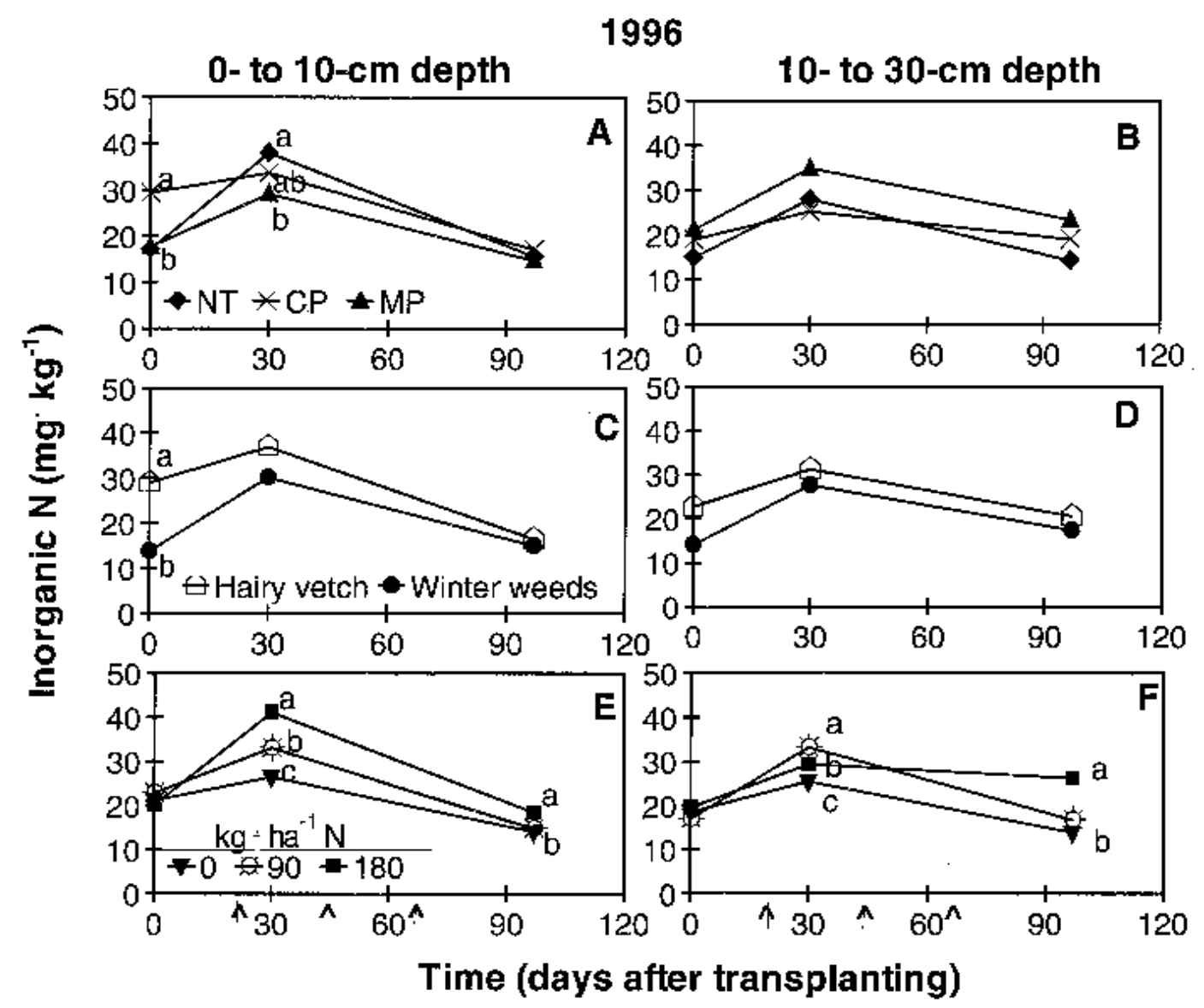

Fig. 1. Soil inorganic $\mathrm{N}$ concentration as influenced by (A, B) tillage, (C, D) cover cropping, and (E, F) N fertilization in 1996. NT denotes no-till; CP, chisel plowing; and MP, moldboard plowing. Mean separation within sampling dates by the least square means test, $P \leq 0.05$. $\uparrow$ denotes time of $\mathrm{N}$ fertilization.

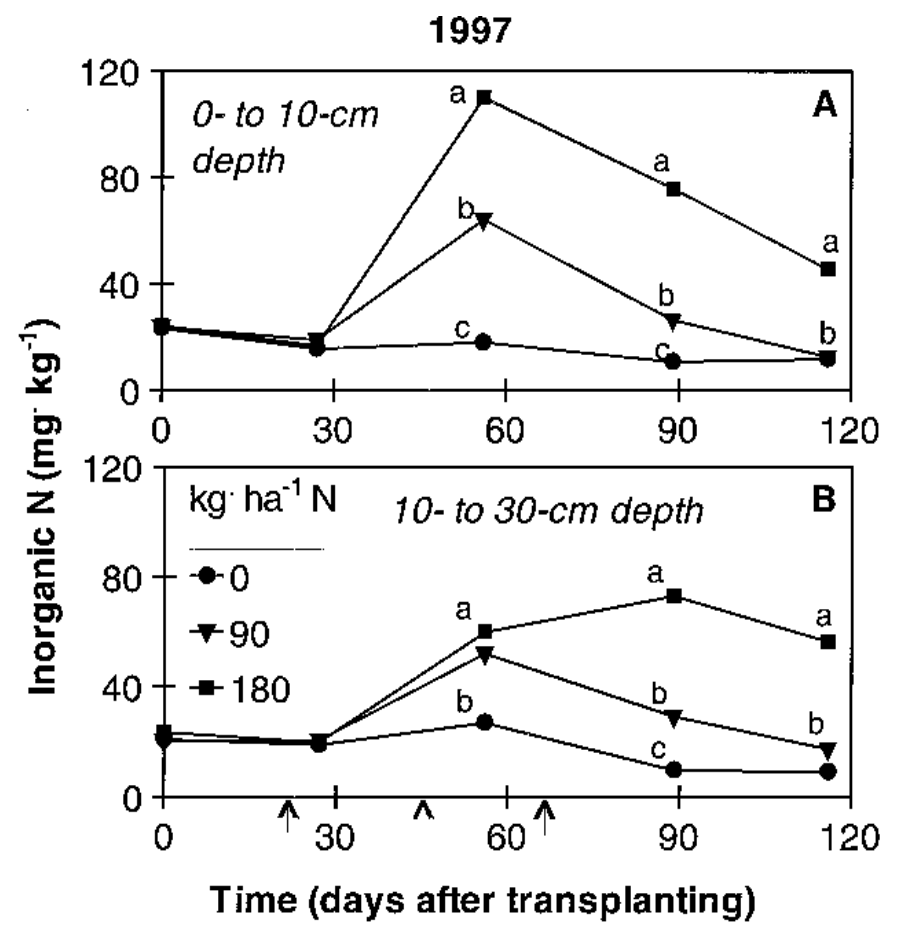

Fig. 2. Soil inorganic $\mathrm{N}$ concentration at (A) 0 - to $10-\mathrm{cm}$ and (B) 10- to $30-\mathrm{cm}$ depths as influenced by $\mathrm{N}$ fertilization in 1997. Mean separation within sampling dates by the least square means test, $P \leq 0.05$. $\uparrow$ denotes time of $\mathrm{N}$ fertilization. accumulation of residual $\mathrm{N}$ after harvest and increases the potential for $\mathrm{N}$ leaching. The greater inorganic $\mathrm{N}$ with 180 than with 90 or 0 $\mathrm{kg} \cdot \mathrm{ha}^{-1} \mathrm{~N}$ from 30 to $118 \mathrm{DAT}$ (Figs. $1 \mathrm{E}$ and 1F) indicates that tomato did not effectively reduce $\mathrm{N}$ in the soil at this high fertility rate. As a result, more $\mathrm{N}$ will probably leach with 180 than with 90 or $0 \mathrm{~kg} \cdot \mathrm{ha}^{-1} \mathrm{~N}$. This suggests that $180 \mathrm{~kg} \cdot \mathrm{ha}^{-1} \mathrm{~N}$ may be excessive or the application of $\mathrm{N}$ fertilizer at 63 DAT may be too late for tomato production. Considering the level of inorganic $\mathrm{N}$ and tomato growth with 90 $\mathrm{kg} \cdot \mathrm{ha}^{-1} \mathrm{~N}, \mathrm{~N}$ for tomato in split doses should be applied within 8 weeks after transplanting to synchronize $\mathrm{N}$ availability from fertilizer with early tomato growth.

Soil inorganic N 6 weeks after incorporation of a variety of cover crops [rye (Secale cereale L.), ryegrass (Lolium multiflorum Lam.), Austrian winter pea (Pisum sativum L.), hairy vetch, and canola (Brassica napus L.)] correlated better with silage corn yield and $\mathrm{N}$ uptake than with inorganic $\mathrm{N} 2$ weeks after incorporation (Kuo et al., 1996). We observed that the level of inorganic $\mathrm{N}$ at 27 to 30 DAT was better correlated with tomato yield, aboveground biomass, and $\mathrm{N}$ uptake at 82 to $118 \mathrm{DAT}$ ( $r=0.57$ to $0.73, P \leq 0.05$ ) than at other times $(r=0.48$ to $0.66, P \leq 0.05)$. This indicates that soil samples should be taken 4 weeks after tomato transplanting (or 6 weeks 
after cover crop incorporation) to better relate tomato yield or $\mathrm{N}$ uptake to soil $\mathrm{N}$ status.

\section{Conclusions}

No-till decreased tomato yield and was generally inferior to the other tillage treatments. Hairy vetch increased aboveground tomato biomass and $\mathrm{N}$ uptake and soil inorganic $\mathrm{N}$ initially but did not increase yield compared with winter weeds. Similarly, N fertilization increased yield, biomass, $\mathrm{N}$ uptake, and inorganic $\mathrm{N}$. The levels of soil inorganic $\mathrm{N}$ and tomato $\mathrm{N}$ uptake indicated that mineralization of $\mathrm{N}$ from cover crop residues was synchronized with $\mathrm{N}$ need of tomato during its early growth and $\mathrm{N}$ should be applied within 8 weeks after transplanting. Because of the similarity in tomato yield, biomass, and $\mathrm{N}$ uptake, minimum tillage, such as $\mathrm{CP}$, is superior to conventional tillage, such as MP, for sustaining tomato yield and reducing the potential for soil erosion. Similarly, application of $90 \mathrm{~kg} \cdot \mathrm{ha}^{-1} \mathrm{~N}$ is better than application of 180 $\mathrm{kg} \cdot \mathrm{ha}^{-1} \mathrm{~N}$ for maintaining tomato yield and reducing the potential for $\mathrm{N}$ leaching. Hairy vetch provides increased vegetative cover in the winter, followed by increased tomato biomass, $\mathrm{N}$ uptake, and soil $\mathrm{N}$ in the summer, thereby reducing the potential for soil erosion and the amount of $\mathrm{N}$ fertilization needed.

\section{Literature Cited}

Abdul-Baki, A.A. and J.R. Teasdale. 1993. A notillage tomato production system using hairy vetch and subterranean clover mulches. HortScience 28:106-108.

Abdul-Baki, A.A., J.R. Teasdale, R. Korcak, D.J. Chitwood, and R.N. Huettel. 1996. Fresh-market tomato production in a low-input alternative system using cover crop mulch. HortScience 31:65-69.

Balesdent, J.A., A. Mariotti, and D. Boisgontier. 1990. Effects of tillage on soil organic carbon mineralization estimated from ${ }^{13} \mathrm{C}$ abundance in maize fields. J. Soil Sci. 41:584 586.

Cambardella, C.A. and E.T. Elliott. 1993. Carbon and nitrogen distribution in aggregates from cultivated and native grassland soils. Soil Sci. Soc. Amer. J. 57:1071-1076.

Collins, H.P., P.E. Rasmussen, and C.L. Douglass, Jr. 1992. Crop rotation and residue management effects on soil carbon and microbial dynamics.
Soil Sci. Soc. Amer. J. 56:783-788.

Creamer, N.G., M.A. Bennett, B.J. Stinner, and J. Cardina. 1996. A comparison of four processing tomato production systems differing in cover crop and chemical inputs. J. Amer. Soc. Hort. Sci. 12:559-568.

Frankenberger, W.T., Jr. and H.M. Abdelmagid. 1985. Kinetic parameters of nitrogen mineralization rates of leguminous crops incorporated into soil. Plant Soil 87:257-271.

Franzluebbers, A.J., F.M. Hons, and D.A. Zuberer. 1995. Tillage and crop effects on seasonal soil carbon and nitrogen dynamics. Soil Sci. Soc. Amer. J. 59:1618-1624.

Frye, W.W., R.L. Blevins, M.S. Smith, and S.J. Corak. 1988. Role of annual cover crops in efficient use of water and nitrogen, p. 129-154. In: W.L. Hargrove (ed.). Cropping strategies for efficient use of water and nitrogen. Spec. Publ. No. 51. Amer. Soc. Agron., Madison, Wis.

Hallberg, G.R. 1989. Nitrate in groundwater in the United States, p. 35-75. In: R.F. Follett (ed.). Nitrogen management and groundwater protection. Elsevier, New York.

Hallberg, G.R., R.D. Libra, and B.E. Hoyer. 1985. Non-point source contamination of groundwater in Karst carbonate aquifers in Iowa. Perspectives on non-point source pollution. Proc. Nat'l. Conf. U.S. Env. Prot, Agency, Washington, D.C.

Hargrove, W.L. 1986. Winter legumes as a nitrogen source for no-till grain sorghum. Agron. J. 78:7074.

Havlin, J.L., D.E. Kissel, L.D. Maddux, M.M. Claasen, and J.H. Long. 1990. Crop rotation and tillage effects on soil organic carbon and nitrogen. Soil Sci. Soc. Amer. J. 54:448-452.

Kaspar, T.C., J. Brown, and E.M. Kassmeyer. 1991 Corn root distribution as affected by tillage, wheel traffic, and fertilizer placement. Soil Sci. Soc. Amer. J. 55:1390-1394.

Kuo, S., U.M. Sainju, and E.J. Jellum. 1996. Winter cover cropping influence on nitrogen mineralization, pre-sidedress soil nitrate test, and corn yields. Biol. Fertil. Soils 22:310-317.

Kuo, S., U.M. Sainju, and E.J. Jellum. 1997. Winter cover cropping influence on nitrogen in soil. Soil Sci. Soc. Amer. J. 61:1392-1399.

Littell, R.C., G.A. Milliken, W.W. Stroup, and R.D. Wolfinger. 1996. SAS system for mixed models. SAS Inst., Cary, N.C.

Lowrance, R. and D. Smittle. 1988. Nitrogen cycling in a multiple crop-vegetable production system. J. Environ. Qual. 17:158-162.

Magdoff, F. 1991. Understanding the Magdoff presidedress nitrate test for corn. J. Prod. Agr. 4:297-305.

Mulvaney, R.L. 1996. Nitrogen-inorganic forms, p.
1123-1184. In: D.L. Sparks, A.L. Page, P.A Helmke, R.H. Loeppert, P.N. Soltanpour, M.A. Tabatabai, C.T. Johnston, and M.E. Sumner (eds.). Methods of soil analysis. Part 3. SSSA Book Ser. 5. Amer. Soc. Agron. and Soil Sci. Soc. Amer., Madison, Wis.

Nelson, D.W. and L.E. Sommers. 1996. Total carbon, organic carbon, and organic matter, p. 9611010. In: D.L. Sparks, A.L. Page, P.A. Helmke, R.H.Loeppert, P.N. Soltanpour, M.A. Tabatabai, C.T. Johnston, and M.E. Sumner (eds.). Methods of soil analysis. Part 3. SSSA Book Ser. 5. Amer. Soc. Agron. and Soil Sci. Soc. Amer., Madison, Wis.

Power, J.F. and J.W. Doran. 1988. Role of crop residue management in nitrogen cycling and use, p. 101-113. In: W.L. Hargrove (ed.). Cropping strategies for efficient use of water and nitrogen. Spec. Publ. No. 51. Amer. Soc. Agron. and Soil Sci. Soc. Amer, Madison, Wis.

Power, J.F. and J.S. Schepers. 1989. Nitrate contamination of groundwater in North America. Agr. Ecosyst. Environ. 26:165-187.

Sainju, U.M. and B.P. Singh. 1997. Winter cover crops for sustainable agricultural systems: Influence on soil properties, water quality, and crop yields. HortScience 32:21-28.

Sainju, U.M., B.P. Singh, and W.F. Whitehead. 1998. Cover crop root distribution and its effects on soil nitrogen cycling. Agron. J. 90:511-518.

Smith, M.S., W.W. Frye, and J.J. Varco. 1987. Legume winter cover crops. Adv. Soil Sci. 7:95139.

Stanford, G., M.H. Frere, and R.A. Van der Pol. 1975. Effect of fluctuating temperatures on soil nitrogen mineralization. Soil Sci. 119:222-226.

Stute, J.K. and J.L. Posner. 1995. Synchrony between legume nitrogen release and corn demand in the upper Midwest. Agron. J. 87:1063-1069.

Sweeney, D.W., D.A. Graetz, A.B. Bottcher, S.J. Locascio, and K.L. Campbell. 1987. Tomato yield and nitrogen recovery as influenced by irrigation method, nitrogen source, and mulch. HortScience 22:27-29.

United States Environmental Protection Agency (USEPA). 1992. Annual needs survey. USEPA, Office of Water, Washington, D.C.

University of Georgia. 1995. Commercial tomato production and management. Bul. 1116. Coop. Ext. Serv., Univ. of Georgia, Athens.

Vigil, M.F. and D.W. Kissel. 1991. Equations for estimating the amount of nitrogen mineralized from crop residues. Soil Sci. Soc. Amer. J. 55:757-761.

Voorhees, W.B. 1983. Relative effectiveness of tillage and natural resources in alleviating wheelinduced soil compaction. Soil Sci. Soc. Amer. J. 47:129-133. 